\title{
FAKTOR-FAKTOR YANG MEMPENGARUHI MINAT NASABAH TERHADAP INTERNET BANKING
}

\section{FACTORS AFFECTING THE INTERESTS OF CUSTOMERS OF INTERNET BANKING}

\author{
Mislah Hayati Nasution ${ }^{1 a}$ Sutisna ${ }^{2}$ \\ 1Jurusan Ekonomi Islam Fakultas Ekonomi Islam Universitas Djuanda, Jl. Tol Ciawi No. 1, Kotak Pos \\ 35 Bogor 16770. \\ 2Jurusan Perbankan Syariah Fakultas Ekonomi Islam Universitas Djuanda, Jl. Tol Ciawi No. 1, Kotak \\ Pos 35 Bogor 16770
}

(DiterimaolehDewanRedaksi:15-03-2012)

(Dipublikasikan oleh Dewan Redaksi:01-01=6-2015 )

\begin{abstract}
ABSTRCT
Internet banking service which is customer service so that the bank obtain information, conduct banking transactions 24 hours a day without being limited by space and time of origin is connected to the Internet network. The method used in the study is quantitative, using a statistical test. The data used are the primary data and secondary data. Primary data is taken directly from the research by distributing questionnaires and interviews are a major source in this study. Of this study concluded that the factors that influence customer interest in using the internet banking service is the factor of convenience, safety, comfort, efficient and practical. And the most dominant factor influencing customers' interest in using the internet banking is the convenience factor. As for the Chi Square indicates there is a positive influence on the perception of usefulness and perceived ease of customer interest in using the internet banking on PT. Bank BNI Syariah Bogor Branch. Perceived ease characterized by $(84.37>11.341)$. And perception of benefit value $(123.2>11.341)$, shows that the calculated Chi Square value is greater than the value of Chi-Square table.
\end{abstract}

Keywords : Interests Of Customers, Internet Banking,

\section{ABSTRAK}

Layanan internet banking yang merupakan pelayanan jasa bank sehingga nasabah memperoleh informasi, melakukan transaksi perbankan 24 jam sehari tanpa dibatasi ruang dan waktu asal terhubung dengan jaringan internet. Metode yang digunakan dalam penelitian adalah kuantitatif, dengan menggunakan test statistik. Data yang digunakan adalah data primer dan data sekunder. Data primer diambil langsung dari tempat penelitian dengan menyebarkan kuisioner dan wawancara yang merupakan sumber utama dalam penelitian ini. Dari penelitian ini diperoleh kesimpulan bahwa faktor-faktor yang mempengaruhi minat nasabah dalam menggunakan layanan internet banking adalah faktor kemudahan, keamanan, kenyamanan, efisien dan praktis. Dan faktor yang paling dominan mempengaruhi minat nasabah dalam menggunakan internet banking adalah faktor kenyamanan. Sedangkan untuk Chi Kuadrat menunjukkan terdapat pengaruh positif antara persepsi kemudahan dan persepsi kemanfaatan terhadap minat nasabah dalam menggunakan internet banking di PT. Bank BNI Syariah Cabang Bogor. Persepsi 
kemudahan ditandai dengan $(84,37>11,341)$. Dan persepsi kemanfaatan bernilai $(123,28>11,341)$, memperlihatkan bahwa nilai Chi Kuadrat hitung lebih besar dari nilai Chi-Kuadrat tabel.

Kata Kunci : Minat Nasabah, Interner Banking

Mislah Hayati Nasution. 2012. Faktor-Faktor Yang Mempengaruhi Minat Nasabah Terhadap Internet Banking . Jurnal Nisbah (1): 62 - 73.

\section{PENDAHULUAN}

Perkembangan Teknologi Informasi (TI) yang sangat pesat dewasa ini memberikan banyak kemudahan pada berbagai aspek kegiatan bisnis. Dimana penerapan TI bagi perusahaan mempunyai peranan penting dan dapat menjadi pusat strategi bisnis untuk memperoleh keunggulan bersaing. Selain itu TI juga sudah menjadi kebutuhan dasar bagi setiap perusahaan terutama dalam menjalankan segala aspek aktifitas bisnis, memberikan informasi dengan cepat, tepat waktu, relevan dan akurat (Dedi, 2007).

Salah satu sektor bisnis yang paling berpengaruh oleh perkembangan TIadalah sektor perbankan. Dan saat ini bankberlomba-lomba menawarkan suatu produk jasa yang fungsinya mendukung berbagai kegiatan perbankan dengan nasabah. Hal ini disebabkanbahwasemakin berkembangnya ilmu pengetahuan dan teknologi sehingga perilaku konsumen (nasabah) mulai banyak berubah. Karena,dalam melakukan suatu transaksi, konsumen sekarang ini sangat mengedepankan aspek kemudahan, fleksibilitas, efisiensi dan kesederhanaan. Kenyataan ini tentunya merupakan tantangan bagi industri perbankan dan muncul kompetisi yang sangat ketat yang berakibat nasabah mempunyai semakin banyak pilihan (Titis, 2008). Oleh karena itu untuk menarik dan mempertahankan para nasabah khususnya nasabah yang sering bergerak (mobile), bank berusaha untuk memenuhi kebutuhan mereka dengan memberikan berbagai pelayanan yang berbasis teknologi diantaranya meliputi; Automated Teller Machine, Banking Application System, Real Time Gross Settlement System dan Internet Banking (Maryanto, 2011).

Layanan Internet Banking diberikan oleh bank dengan tujuan utama memberikan kemudahan kepada nasabah. Pelayanan perbankan melalui internet tersebut berupa situs dari suatu bank tertentu yang menyediakan pelayanan perbankan langsung, tanpa perlu datang ke bank yang bersangkutan. Dengan adanya situs ini, nasabah suatu bank akan semakin mudah untuk melakukan kegiatan perbankan karena mereka dapat mengakses situs tersebut dan menggunakan fitur-fitur yang ada di dalamnya seperti cek saldo, mutasi rekening sampai transfer, melakukan pembayaran tagihan, pembelian voucher prabayar, dan lain-lain, di mana saja dan kapan saja, asal memiliki koneksi ke internet (Ratih, 2009).

Dengan adanya Internet bankingakanmemberikan keuntungan bagi beberapa pihak, baik kepada pihak nasabah maupun pihakperbankanitu sendiri. Salah satu keuntunganbagi nasabah yaitudapat memberikan kemudahan dalam melakukan transaksi perbankan serta menghemat waktu dan biaya. Selain itu, dari sisi pihak perbankan internet banking dapat meningkatkan kinerja (performance) bank dan biaya untuk memberikan layanan perbankan dapat lebih murah dibandingkan dengan membuka kantor cabang (Hadri dan Dwi, 2007). Namun jika layanan tersebut tidak dimanfaatkan dengan maksimal, maka kesuksesan inovasi teknologi tersebut tidak akan 
diperoleh. Sebab hal itu secara langsung tergantung dari penerimaan dan persepsi konsumen (nasabah) terhadap teknologi tersebut. Oleh karena itu, penting bagi pihak bank untuk mengetahui bagaimana para nasabah mengapresiasi layanan internet banking agar dapat membantu menemukan rencana strategis dan meningkatkan pangsa pasar (Ratih, 2009).

Nasabah merupakan pelanggan (customer) baik individu maupun perusahaan yang mendapatkan manfaat atau kegunaan dari produk dan jasa dari sebuah perusahaanmperbankan, meliputi kegiatan pembelian, penyewaan, serta layanan jasa. Sedangkan minat merupakan perhatian, kesukaan, kesenangan, ketertarikan (kecocokan hati) kepada sesuatu ataupun keinginan terhadap sesuatu. Oleh sebab itu, perlu adanya keterpaduan baik internal maupun eksternal, baik dalam lingkup proses maupun implementasi, serta keleluasaan dan kedalaman implementasi dari layanan tersebut (Mieke, 2008).

Salah satu bank syariah yang telah menyediakan layanan internet banking adalah PT. Bank BNI Syariah, seiring dengan diterapkannya internet banking diharapkan bank memperoleh hasil yang maksimal. Dari permasalahan di atas maka penulis tertarik untuk mengkaji dan meneliti lebih dalam lagi mengenai "Faktor-Faktor Yang Mempengaruhi Minat Nasabah Terhadap Internet Banking".

\section{Tujuan Penelitian}

1. Mengetahui faktor-faktor yang mempengaruhi minat nasabah terhadap layanan internet banking.

2. Mengetahui faktor yang paling dominan mempengaruhi minat nasabah terhadap layanan internet banking.

\section{Manfaat Penelitian}

Penelitian ini diharapkan dapat memberikan tambahan ilmu pengetahuan serta memberikan kontribusi berupa informasi mengenai faktor-faktor yang mempengaruhi minat nasabah untuk menggunakan layanan internet banking.

\section{Hipotesis Penelitian}

Hipotesis dalam penelitian ini sebagai berikut:

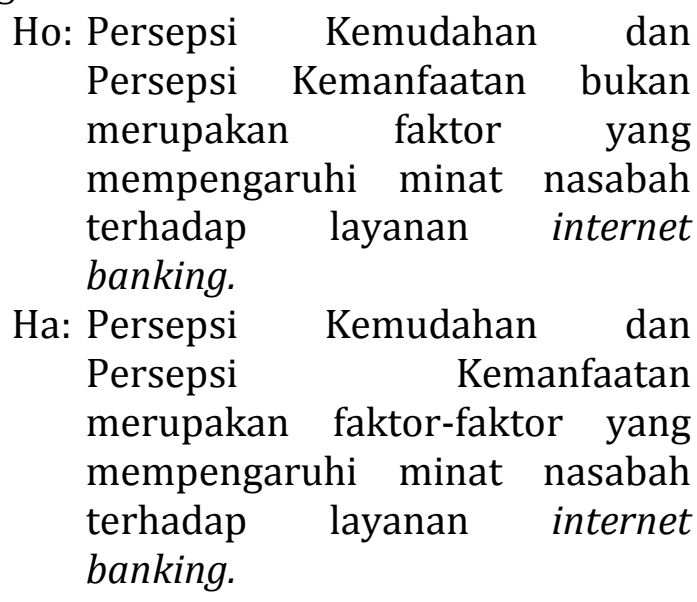

\section{MATERI DAN METODE}

\section{Pengertian Faktor}

Faktor adalah sesuatu hal, keadaan, peristiwa dan sebagainya yang ikut menyebabkan, mempengaruhi terjadinya sesuatu yang merupakan bagian hasil perbanyakan (Dwi, 2001). Dan adapun faktor-faktor yang menjadi penyebab seseorang tertarik akan sesuatu hal dapat dipengaruhi oleh faktor ekternal maupun internal. Faktor-faktor tersebut akan dijelaskan pada pembahasan selanjutnya.

\section{Pengertian Minat}

Pengertian minat adalah gejala psikologis yang menunjukkan pemusatan perhatian terhadap suatu obyek sebab ada perasaan senang (Tidjan, 2010). Minat merupakan perhatian, kesukaan, kesenangan, ketertarikan (kecocokan hati) kepada sesuatu ataupun keinginan terhadap sesuatu (KBBI). Minat dapat direalisasikan dengan cara mengarahkan potensi rasio menuju tanggapan seseorang terhadap bidang tertentu. Tanggapan tersebut bisa berupa reaksi internal atau eksternal. Minat akan muncul jika kita memiliki bentuk pilihan atau pandangan terhadap suatu hal atau obyek yang dapat 
dijangkau indera maupun yang terlahir dari pikiran-pikiran individual (Najib, 2004).

\section{Pengertian Nasabah}

Nasabah adalah pelanggan (costumer) yaitu individu atau perusahaan yang mendapatkan manfaat atau produk dan jasa dari sebuah perusahaan perbankan, meliputi kegiatan pembelian, penyewaan serta layanan jasa. Sedangkan nasabah menurut pasal 1 ayat (17) UU No.10 tahun 1998 adalah "Pihak yang menggunakan jasa bank." Nasabah mempunyai peran penting dalam industri perbankan, dimana dana yang disimpan nasabah di bank merupakan dana yang terpenting dalam operasional bank untuk menjalankan usahanya.

\section{Perilaku Konsumen}

Seiring berkembangnya teknologi, berkembang pula strategi yang harus dijalankan oleh suatu perusahaan termasuk bank. Dalam menentukan jenis produk atau jasa, konsumen selalu mempertimbangkan tentang produk atau jasa apa yang dibutuhkan, hal ini dikenal dengan perilaku konsumen. Oleh karena itu sebelum suatu jasa diciptakan, maka perusahaan (bank) perlu untuk mengetahui apa dan bagaimana yang menjadi keinginan konsumen terhadap suatu jasa tersebut. Bank perlu sekali untuk dapat mempelajari perilaku dari konsumen atau nasabah, sehingga perusahaan (bank) akan dapat menentukan jenis produk jasa apa yang harus diproduksi atau diciptakan.

Perilaku konsumen dapat didefinisikan sebagai kegiatan-kegiatan individu yang secara langsung terlibat dalam mendapatkan dan mempergunakan barang dan jasa, termasuk didalamnya proses pengambilan keputusan pada persiapan dan penentuan kegiatankegiatan tersebut. Perilaku konsumen akan menentukan proses pengambilan keputusan dalam pembelian. Proses tersebut merupakan pendekatan penyelesaian masalah pada kegiatan manusia untuk membeli suatu barang atau jasa dalam memenuhi keinginan dan kebutuhanya.

\section{Pengertian Teknologi Informasi}

Teknologi informasi adalah studi atau penggunaan peralatan elektronika, terutama komputer untuk menyimpan, menganalisis dan mendistribusikan informasi dalam bentuk apapun termasuk kata-kata, bilangan dan gambar. Dan menurut Alter teknologi informasi adalah mencakup perangkat keras dan perangkat lunak untuk melaksanakan satu atau sejumlah tugas pemrosesan data seperti menangkap, mentransmisikan, menyimpan, mengambil, memanipulasi, atau menampilkan data. Sedangkan Lucas menyatakan secara lebih umum bahwa teknologi informasi adalah segala bentuk teknologi yang diterapkan untuk memproses dan mengirimkan informasi dalam bentuk elektronik (Gilang, 2010). Menurut Kadir yang dikutip dari penelitian Gilang R. Amijaya yang berjudul "Pengaruh perspsi teknologi informasi, kemudahan, resiko dan fitur layanan terhadap minat ulang nasabah bank dalam menggunakan internet banking (studi pada nasabah bank BCA)", peranan teknologi informasi meliputi:

1. Teknologi informasi menggantikan peran manusia. Dalam tugas ini, teknologi informasi melakukan otomasi terhadap suatu tugas atau proses.

2. Teknologi informasi memperkuat peran manusia, yakni dengan menyajikan informasi terhadap suatu tugas atau proses.

3. Teknologi informasi berperan dalam melakukan perubahan-perubahan terhadap sekumpulan tugas atau proses.

\section{Technology Acceptance Model (TAM)}

Technology Acceptance Model (TAM) adalah teori yang menjelaskan penerimaan individu terhadap penggunaan sistem 
informasi. TAM pertama kali diperkenalkan oleh Davis F.D pada tahun 1989, yang merupakan salah satu model yang paling banyak digunakan dalam penelitian teknologi informasi karena model ini lebih sederhana dan mudah diterapkan.

Technology Acceptance Model (TAM) di kembangkan untuk memahami persepsi pengguna dalam mengadopsi suatu teknologi informasi (Titis, 2008). Davis menyatakan bahwa keputusan untuk menggunakan teknologi informasi dipengaruhi oleh faktor-faktor sebagai berikut:

1. Persepsi Kemudahan(Perceived Ease of Use)adalah Persepsi tentang kemudahan penggunaan sebuah teknologi yang didefinisikan sebagai suatu ukuran dimana seseorang percaya bahwa teknologi tersebut dapat dengan mudah dipahami dan digunakan.

2. Persepsi Kemanfaatan (Perceived Usefulness) adalah Persepsi terhadap kemanfaatan didefinisikan sebagai suatu ukuran dimana penggunaan suatu teknologi dipercaya akan mendatangkan manfaat bagi orang yang menggunakannya.

Kedua faktor yang tersebut di atas merupakan variabel penting yang menentukan penerimaan terhadap teknologi informasi. Dimana, Davis menemukan bahwa faktor kebermanfaatan secara signifikan berhubungan dengan penggunaan teknologi saat ini dan mampu memprediksi penggunaan yang akan dating (Shinta, 2009).

\section{Pengertian Layanan}

Layanan adalah suatu proses interaksi yang terdiri dari beberapa aktivitas yang dilakukan secara langsung maupun tidak langsung dari perusahaan kepada para customer atau pelanggannya. Layanan (pelayanan) sangat diperhatikan oleh custumer (nasabah), jika suatu bank memberikan layanan yang baik maka akan memeberi kepuasan terhadap nasabah, seperti halnya yang telah disebutkan oleh Kasmir (Mieke, 2008) bahwa nasabah memperoleh kepuasan salah satunya dari tersedianya sarana dan prasarana yang baik, melayani secara cepat dan tepat.

\section{Pengertian Internet Banking}

Pengertian internet banking menurut Karen furst adalah sebagai berikut:

"Internet banking is the use of the internet as remote delivery channel for banking services, including traditional services, such as opening a deposit account on transferring funds among different account, as well as new banking services, such as electronic bill presentment and payment, wich allow customers to receive and pay bill over bank's website (Nadia, 2009).

Dari pengertian di atas dapat di defenisikan secara sederhana bahwa internet banking merupakan suatu bentuk pemanfaatan media internet oleh bank untuk mempromosikan dan sekaligus melakukan transaksi online, baik dari produk yang sifatnya konvensional maupun yang baru. Internet banking pertama kali muncul di Amerika Serikat pada pertangahan tahun 1990-an. Dimana lembaga keuangan di Amerika Serikat memperkenalkan dan mempromosikan internet banking untuk menyediakan layanan perbankan yang lebih baik (Ratih, 2009).

Kehadiran internet bankingakan dapat meningkatkan efisiensi, efektivitas, dan produktivitas, sekaligus meningkatkan pendapatan melalui sistem penjualan yang jauh lebih efektif dibandingkan dengan sistem konvensional.Internet banking memberikan beberapa keuntungan bagi bank, diantaranya sebagai berikut (Ratih, 2009):

1. Business Expansion

2. Custumer Loyalty

3. Revenue and Cost Improveiment

4. Competitive Advantage

5. New Business Model

Pada awalnya Internet banking digunakan untuk iklan dan kegiatan 
promosi untuk produk-produk dan jasa bank. Namun sekarang internet banking telah menciptakan nilai bank-bank dalam hal mengurangi biaya, meningkatkan layanan pelanggan, dan peningkatan keuntungan jangka panjang dengan

\section{Kerangka Pemikiran}

TAM adalah salah satu model evaluasi kesuksesan sistem teknologi informasi dilihat dari penggunaan sistem, yang akan memberikan gambaran bahwa faktor perceived usefulness dan Perceived memungkinkan pelanggan untuk melakukan transaksi online dan melakukan aktivitas lain pada setiap saat tanpa mengenal tempat dan waktu (Mohammed, 2011).

Ease of Use mempengaruhi keputusan pengguna dalam menggunakan teknologi informasi (Arif, 2008). Sebagaimana skemanya dapat dilihat sebagai berikut.

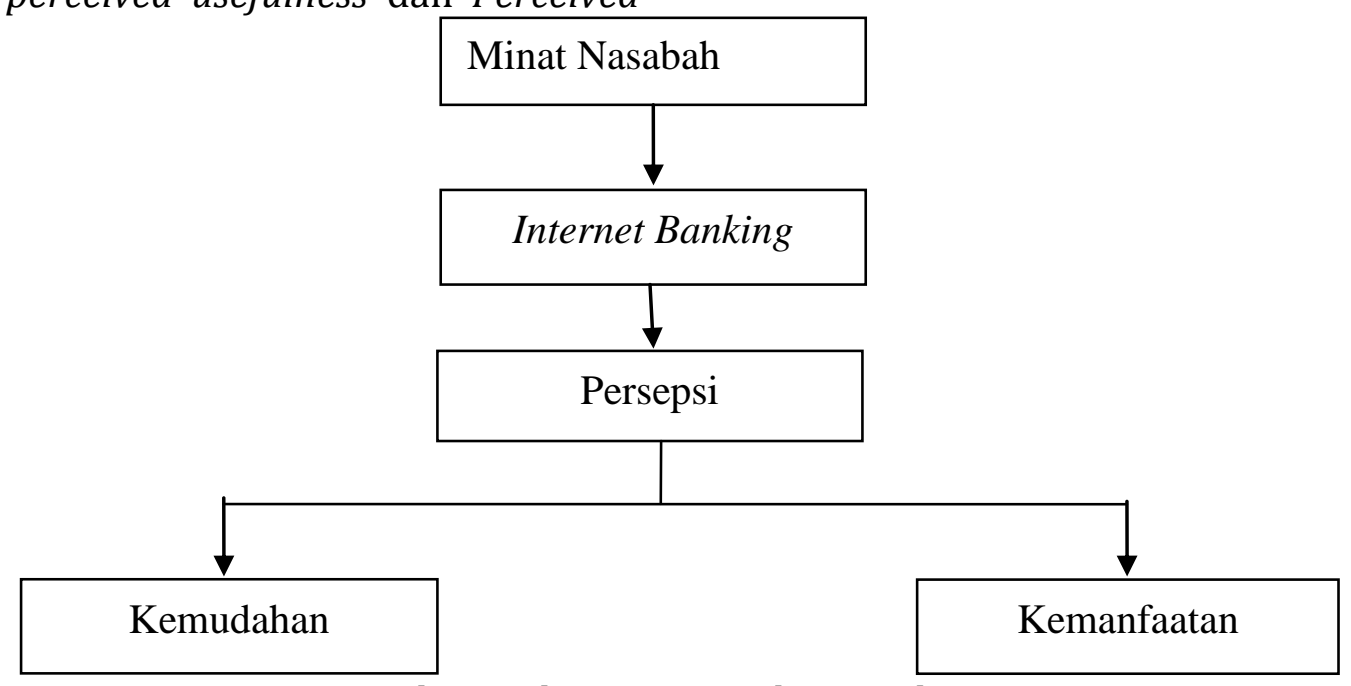

Gambar 1 Skema Kerangka Pemikiran

Pada skema Technology Acceptance ModelTAM di atas terlihat bahwaPerceivedusefulnessdanperceived ease of usemempengaruhi penggunaan sistem (actual system use) melalui sebuah variabel intervening yakni intensitas penggunaan (behavioural intention to use). (Oktavianti, 2008). Namun menurutGahtani

Skema di atas dijelaskan bahwa salah satu strategi bank untuk dapat bersaing khususnya menarik minat nasabah sehingga menyimpan uangnya di bank, maka bank selalu berusaha meningkatkan kualitas produk maupun jasa. Seperti memberikan layanan yang mempermudah nasabah dalam bertransaksi melalui internet banking. Namun nasabah akan dalam penelitian Oktavianti dinyatakan bahwa intensitaspenggunaan danpenggunaan sistem dapat digantikan oleh variabel penerimaan terhadap Teknologi Informasi (Acceptance).Oleh karena itu dalam penelitian ini model yang akan digunakan oleh penulis sebagai berikut.

mengadopsi internet banking apabila adanya minat untuk menggunakan layanan tersebut. Dimana, banyak faktor yang mempengaruhi minat nasabah sehingga tertarik untuk menggunakan internet bankingsalah satunya yang disebabkan oleh persepsi kemudahan dan persepsi manfaat 


\section{MATERI DAN METODE}

Jenis penelitian yang digunakan dalam penelitian ini adalah menggunakan test statistik. Dan sumber data di ambil dari data primer dengan memberikan kuesioner dan wawancara kepada responden terpilih. Sedangkan data sekunder di ambil dari buku-buku, jurnal, artikel, internet dan literatur yang berkaitan dengan penelitian ini.

Populasi dalam penelitian ini adalah Nasabah Bank BNI Syariah Cabang Bogor yang berjumlah 13.000 orang. Dan sampelnya adalah nasabah Bank BNI Syariah Cabang Bogor yang pernah menggunakan maupun yang belum pernah menggunakan internet banking. Sampel dalam penelitian ini yaitu berjumlah 100 orang. Penentuan jumlah sampel dalam penelitian ini menggunakan metode Slovin dengan rumus: $\mathrm{n}=\mathrm{N} / \mathrm{N} \cdot \mathrm{d}^{2}+1$

Teknik pengambilan sampel yang digunakan adalah Simple Random Sampling (Ronny). Teknik pengumpulan data yang digunakan dalam penelitian ini adalah Wawancara, Kuesioner dan Studi kepustakaan. Dan teknik analisis datayang dilakukan dalam penelitian ini dengan menggunakan Statistik Deskriptif (Frequency), Skala Likert dan Test ChiKuadrat (Chi-Square)

\section{HASIL DAN PEMBAHASAN}

Dalam penelitian ini responden yang diteliti berjumlah 100 orang. Adapun yang dilihat dalam penelitian ini dilihat dari karakteristik nasabah yang terdiri dari jenis kelamin, usia, pendidikan, pekerjaan dan pendapatan perbulan.Berdasarkan hasil penelitian ytang dilakukan responden yang menggunakan internet banking adalah jenis kelamin laki-laki yang berjumlah 54 orang (54\%), sedangkan jenis kelamin perempuan berjumlah 46 orang (46\%). Hal ini mengindikasikan bahwa laki-laki lebih tertarik menggunakan internet banking dari perempuan. Dan usia yang paling dominan dalam menggunakan internet banking adalah responden yang berusia 1825 tahun yang berjumlah 40 orang (40\%). Karena mayoritasyang paling banyak menggunakan internet banking adalah remaja atau dewasa, dimana rata-rata yang membutuhkan layanan internet banking adalah remaja atau dewasa.

Dari hasil data yang dikumpulkan responden tingkat pendidikan yang paling dominan adalah sarjana yaitu berjumlah 37 orang (37\%). Sedangkan responden (nasabah) yang berpendidikan selain SLTA/Sederajat, Diploma, Sarjana dan Master hanyaberjumlah 6 orang (6\%). Hal ini mengindikasikan bahwa Semakin tinggi tingkat pendidikan seseorang semakin rasional dalam mempertimbangkan suatu keputusan. Sedangkan jenis pekerjaan responden yang paling banyak dalam penelitian ini adalah responden yang berprofesi sebagai pegawai swasta, yaitu sebanyak 50 orang (50\%) dan yang berprofesi lainnya haya 8 orang (8\%).Berdasarkan dari hasil jawaban responden tersebut, yang paling banyak menggunakan internet banking adalah pegawai swasta karena rata-rata mereka menggunakan internet banking untuk cek saldo, pembayaran tagihan dan pembelian voucher. Selain pegawai swasta juga responden yang berprofesi sebagai mahasiswa dan wiraswasta telah banyak yang telah menggunakan internet banking.

Berdasarkan hasil penelitian ini kelompok pendapatan responden yang paling dominan yaitu pada pendapatan perbulan dari Rp 1.000.000 - 3.000.000 sebanyak 36 orang (36\%). di atas mengindikasikan bahwa responden (nasabah) yang dominan menggunakan internet banking adalah nasabah yang berpenghasilan Rp. 1.000.000 - 3.000.000 per bulan sebab mayoritas nasabah yang berpenghasilan $<1.000 .000$ per bulan adalah mahasiswa, dimana mereka menggunakan internet banking hanya mengakses melalui transaksi non financial. 
Perhitungan Skala Likert Pengetahuan Nasabah tentang Keberadaan Internet Banking

Dari hasil penelitian ini nasabah yang mengetahui keberadaan internet banking sebanyak 55 orang (55\%). Sedangkan nasabah yang tidak mengetahui keberadaan internet banking ada 10 orang (10\%). Dari perolehan angka kriteria penafsiran $\mathrm{M}=2,97$ menunjukkan bahwa nasabah rata-rata mengetahui tentang keberadaan internet banking.

\section{Pengalaman Nasabah dalam Menggunakan Internet Banking}

Dari hasil jawaban responden (nasabah) dapat dilihat bahwa nasabah (responden) yang telah pernah menggunakan internet banking ada 37 orang (37 \%). Sedangkan yang belum pernah berjumlah 33 orang (33\%). Dari perolehan angka kriteria penafsiran $\mathrm{M}=$ 2,52 menunjukkan bahwa responden (nasabah) telah pernah menggunakan internet banking.

\section{Minat Nasabah untuk menggunakan internet banking}

Hasil dari data yang telah dikumpulkan, menjelaskan bahwa sebagian responden "setuju" untuk menggunakan internet banking yaitu sebanyak 22 orang (61,1\%). Sedangkan yang "tidak setuju" adalah sebanyak 6 orang $(16,67 \%)$. Dari perolehan angka kriteria penafsiran $\mathrm{M}=$ 2,67 menunjukkan bahwa responden (nasabah) berminat untuk menggunakan internet banking.

Tempat Nasabah dalam Mengakses

\section{Internet Banking}

\section{a. Mengakses Internet Banking dari}

\section{Rumah}

Dari hasil jawaban responden (nasabah) yang menjawab "setuju" bahwa responden mengakses internet banking dirumah berjumlah 29 orang $(45,31 \%)$, dan yang "tidak setuju" ada 11 orang $(17,19 \%)$. Responden yang menjawab "sangat setuju" berjumlah 18 orang $(28,12)$, dan yang "kurang setuju" ada 6 orang (9,38\%). Dari perolehan angka kriteria penafsiran $\mathrm{M}$ $=2,84$ menunjukkan bahwa responden (nasabah) rata-rata mengakses internet banking dari rumah sebab lebih aman.

\section{b. Mengakses Intenet Banking Dari Kantor}

Berdasarkan dari hasil jawaban responden (nasabah) yang menjawab "setuju" bahwa responden mengakses internet banking di kantor sebanyak 30 orang $(46,87 \%)$ dan yang "tidak setuju" ada 11 orang $(17,19 \%)$. Responden yang menjawab "sangat setuju" berjumlah 11 orang $(17,19 \%)$, dan yang "kurang setuju" ada 12 orang $(18,75 \%)$. Dari perolehan angka kriteria penafsiran $\mathrm{M}=2,64$ menunjukkan bahwa responden (nasabah) mengakses internet banking dari kantor.

\section{c. Mengakses Internet Banking Dari} Warnet

Berdasarkan jawaban responden (nasabah) yang menjawab "setuju" bahwa responden mengakses internet banking di warnet berjumlah 4 orang $(6,25 \%)$ dan yang "tidak setuju" ada 41 orang (64,07\%). Responden yang menjawab "sangat setuju" berjumlah 4 orang $(6,25 \%)$, dan yang "kurang setuju" ada 15 orang $(23,43 \%)$. Dari perolehan angka kriteria penafsiran $\mathrm{M}$ $=1,55$ menunjukkan bahwa rata-rata responden (nasabah) tidak mengakses internet banking dari warnet

d. Lainnya ( selain rumah, kantor dan warnet)

Hasil jawaban responden (nasabah) dapat dilihat yang menjawab "setuju" bahwa responden mengakses internet banking selain di rumah, kantor dan warnet berjumlah 22 orang $(34,38 \%)$ dan yang "tidak setuju" ada 17 orang (26,56\%). Responden yang menjawab "sangat setuju" berjumlah 16 orang (25\%), dan yang "kurang setuju" ada 9 orang $(14,06 \%)$. Dari perolehan angka kriteria penafsiran $\mathrm{M}=2,58$ 
menunjukkan bahwa banyak responden (nasabah) yang mengakses internet banking selain di rumah, kantor dan warnet.

\section{Jumlah dalam Mengakses Internet Banking}

a. Akses Internet Banking $<10$ kali perbulan

Berdasarkan jawaban responden (nasabah) yang menjawab "setuju" bahwa responden mengakses internet banking dalam sebulan sebanyak $<10$ kali berjumlah 35 orang $(54,69 \%)$ dan yang "tidak setuju" ada 9 orang $(14,06 \%)$. Responden yang menjawab "sangat setuju" berjumlah 9 orang $(14,06 \%)$, dan yang "kurang setuju" ada 11 orang $(17,19 \%)$. Dari perolehan angka kriteria penafsiran $\mathrm{M}=3,78$ menunjukkan bahwa rata-rata responden (nasabah) mengakses internet banking $<10$ kali dalam sebulan.

b. Akses Internet Banking>10 kali per bulan

Dari hasil jawaban responden (nasabah) yang menjawab "setuju" bahwa responden mengakses internet banking per bulan sebanyak $>10$ kali berjumlah 19 orang $(29,69 \%)$ dan yang "tidak setuju" ada 31 orang (48,43\%). Responden yang menjawab "sangat setuju" berjumlah 7 orang $(10,94 \%)$, dan yang "kurang setuju" ada 7 orang $(10,94 \%)$. Dari perolehan angka kriteria penafsiran $\mathrm{M}=2,03$ menunjukkan bahwa tidak banyak responden (nasabah) yang mengakses internet banking $>10$ kali dalam sebulan

\section{c. Akses Internet Banking $>20$ kali perbulan}

Hasil dari jawaban responden (nasabah) yang menjawab "setuju" bahwa responden mengakses internet banking per bulan sebanyak $>20$ kali berjumlah 5 orang $(7,81 \%)$ dan yang "tidak setuju" ada 41 orang $(64,06 \%)$. Responden yang menjawab "sangat setuju" berjumlah 14 orang $(21,88 \%)$, dan yang "kurang setuju" ada 4 orang $(6,25 \%)$. Dari perolehan angka kriteria penafsiran $\mathrm{M}=1,88$ menunjukkan bahwa hanya sedikit responden (nasabah) yang mengakses internet banking $>20$ kali dalam sebulan.

\section{Persepsi Nasabah Tentang Kemudahan}

Dari hasil jawaban responden (nasabah) yang menjawab persepsi nasabah tentang kemudahan, menunjukkan bahwa responden (nasabah) yang menjawab "sangat setuju" berjumlah 166 (33,2\%), "setuju" berjumlah 266 (53,2\%), "kurang setuju" dan "tidak setuju" berjumlah 68 (13,6\%). Dari perolehan angka kriteria penafsiran $\mathrm{M}=3,16$ menunjukkan bahwa persepsi kemudahan merupakan hal yang sangat berpengaruh dalam keputusan nasabah untuk menggunakan internet banking.

\section{Persepsi Nasabah Tentang Keamanan}

Berdasarkan data primer yang dikumpulkan melalui penyebaran kuisioner, jawaban responden (nasabah) tentang keamanan dalam menggunakan internet bankingmenjelaskan bahwa respon nasabah akan persepsi tentang keamanan "sangat setuju" sebesar $69 \quad(17,25 \%)$, "setuju" sebesar 161 (40,25\%), kurang setuju dan tidak setuju 170 (42,5\%). Dari perolehan angka kriteria penafsiran $\mathrm{M}=$ 2,63 menunjukkan bahwa rata-rata responden (nasabah) menyatakan keamanan berpengaruh terhadap keputusan responden (nasabah) dalam menggunakan internet banking sebab keamanan dapat menghindari terjadinya modus phishing. Adapun langkah yang diberikan BNI Syariah untuk memaksimalkan keamanan internet banking yaitu dengan menggunakan $e$ secure.

\section{Persepsi Nasabah Tentang Kenyamanan}

Dari jawaban responden (nasabah) tentang kenyamanan dalam menggunakan internet banking menjelaskan bahwa respon (nasabah) akan persepsi tentang kenyamanan "sangat setuju" sebesar 230 
(57,5\%), "setuju" sebesar $37 \quad(9,25 \%)$, kurang setuju dan tidak setuju 46 (11,5\%). Dari perolehan angka kriteria penafsiran M $=3,18$ menunjukkan bahwa persepsi nasabah tentang kenyamanan merupakan hal yang sangat atau dominan berpengaruh terhadap keputusan nasabah dalam menggunakan internet banking.

\section{Persepsi Nasabah Tentang Efisien}

Dari penelitian yang telah dilakukan hasil responden (nasabah) yang memperlihatkan persepsi nasabah tentang efisien dalam menggunakan internet bankingdapat di simpulkan bahwa responden mayoritas menjawab "setuju" tentang efisien sebanyak 171 (42,75\%) "sangat setuju" sebesar $70 \quad(23,33 \%)$, sedangkan "kurang setuju" dan "tidak setuju" 59 (19,67\%). Dari perolehan angka kriteria penafsiran $\mathrm{M}=3,01$ menunjukkan bahwa persepsi nasabah tentang efisien berpengaruh terhadap keputusan nasabah dalam menggunakan internet banking.

\section{Persepsi Nasabah Tentang Praktis}

Berdasarkan penelitian yang telah dilakukan, persepsi nasabah tentang Tabel 1 Frekuensi Yang Diobservasi Dan Yang Diharapkan Dari Minat

Berdasarkan Persepsi Kemudahan

\begin{tabular}{lccccc}
\hline \multicolumn{1}{c}{ Kategori } & $\mathrm{f}_{\mathrm{o}}$ & $\mathrm{f}_{\mathrm{h}}$ & $\left(\mathrm{f}_{\mathrm{o}}-\mathrm{f}_{\mathrm{h}}\right)$ & $\left(\mathrm{f}_{\mathrm{o}}-\mathrm{f}_{\mathrm{h}}\right)^{2}$ & $\frac{\left(\mathbf{f}_{\mathbf{o}}-\mathbf{f}_{\mathbf{h}}\right)^{2}}{\mathbf{f}_{\mathbf{h}}}$ \\
\hline Sangat Setuju & 278 & 225.5 & 52.5 & $2,756.25$ & 12.22 \\
Setuju & 487 & 225.5 & 261.5 & $68,382.25$ & 303.24 \\
Kurang Setuju & 106 & 225.5 & -119.5 & $-14,280.25$ & -63.32 \\
Tidak Setuju & 31 & 225.5 & -194.5 & $-37,830.25$ & -167.77 \\
Jumlah & 902 & 902 & 0 & 19,028 & 84.38 \\
\hline
\end{tabular}

Sumber : Kuesioner, data diolah

Dari hasil perhitungan pada tabel di atas maka nilai Chi-Kuadrat hitung $=84,37$. Dimana dalam hal ini $\mathrm{dk}=\mathrm{n}-1=4-1=3$. Berdasarkan dk (derajat kebebasan) $=3$ dengan taraf signifikan 1\%, maka diperoleh nilai Chi-Kuadrat tabel $=11,341$. Dapat dilihat bahwa ternyata chi kuadrat hitung

lebih besar dari nilai Chi-Kuadrat tabel $(84,37>11,341)$. Dengan demikian $\mathrm{H}_{0}$ praktis, menjelaskan bahwa respon (nasabah) akan persepsi tentang kenyamanan "sangat setuju" sebesar 112 (28\%), "setuju" sebesar 221 (73,67\%), kurang setuju dan tidak setuju 67 (16,75\%). Dari perolehan angka kriteria penafsiran $\mathrm{M}=3,09$ menunjukkan bahwa persepsi nasabah tentang praktis mempengaruhi keputusan nasabah untuk menggunakan internet banking.

\section{Analisis Test Chi-Square (Chi Kuadrat)}

Dalam penelitian ini responden (nasabah) memilih jawaban bahwa salah satu faktor-faktor yang mempengaruhi minat nasabah terhadap internet banking dapat dipengaruhi oleh beberapa faktor persepsi responden (nasabah), dan harus di uji terlebih dahulu atas keputusan responden (nasabah) untuk mengetahui ada pengaruh atau tidaknya. Dan alat uji yang dipakai dalam penelitian ini adalah alat analisis Chi Square (Chi Kuadrat).

Di bawah ini merupakan perhitungan dan analisa Chi Kuadrat bagi variabel minat nasabah terhadap internet banking berdasarkan persepsi kemudahan. 
dari usia, pendidikan, pekerjaan dan pendapatan perbulan. Tabel 3 Frekuensi Yang Diobservasi Dan Yang Diharapkan Dari Minat Berdasarkan Persepsi Kemanfaatan

\begin{tabular}{lccccc}
\hline \multicolumn{1}{c}{ Kategori } & $\mathrm{f}_{\mathrm{o}}$ & $\mathrm{f}_{\mathrm{h}}$ & $\left(\mathrm{f}_{\mathrm{o}}-\mathrm{f}_{\mathrm{h}}\right)$ & $\left(\mathrm{f}_{\mathrm{o}}-\mathrm{f}_{\mathrm{h}}\right)^{2}$ & $\frac{\left(\mathbf{f}_{\mathbf{o}}-\mathbf{f}_{\mathbf{h}}\right)^{\mathbf{2}}}{\mathbf{f}_{\mathbf{h}}}$ \\
\hline Sangat Setuju & 263 & 275 & -12 & -144 & -0.52 \\
Setuju & 562 & 275 & 287 & 82,369 & 299.52 \\
Kurang Setuju & 210 & 275 & -65 & $-4,225$ & -15.37 \\
Tidak Setuju & 65 & 275 & -210 & $-44,100$ & -160.37 \\
Jumlah & 1100 & 1100 & 0 & 33900 & 123.28
\end{tabular}

\section{Sumber : Kuesioner, data diolah}

Berdasarkan dari hasil perhingan yang di tunjukkan pada tabel di atas, maka nilai Chi-Kuadrat hitung 123,28. Dalam hal ini $\mathrm{dk}=\mathrm{n}-1=4-1=3$. Dari $\mathrm{dk}$ (derajat kebebasan) $=3$ dengan taraf signifikansi 1\%, maka diperoleh nilai Chi Kuadrat tabel $=11,341 \quad(123,28>11,341)$. Dengan demikian $\mathrm{H}_{0}$ ditolak dan $\mathrm{H}_{\mathrm{a}}$ diterima.

Dari hasil di atas, dapat di ketahui bahwa persepsi kemanfaatan ternyata memberikan pengaruh terhadap minat nasabah untuk menggunakan internet banking di BNI Syariah Cabang Bogor.

\section{KESIMPULAN DAN IMPLIKASI}

Berdasarkan dari tujuan yang ingin dicapai oleh peneliti dalam penelitian ini dapat ditarik sebuah kesimpulan.

1. Faktor-faktor yang mempengaruhi minat nasabah dalam menggunakan layanan internet

banking di PT. Bank BNI Syariah Cabang Bogor adalah salah satunya faktor kemudahan, keamanan, kenyamanan, efisien dan praktis.

2. Faktor yang paling dominan mempengaruhi minat nasabah dalam menggunakan internet banking di PT. Bank BNI Syariah

Cabang Bogor adalah faktor kenyamanan.
3. Kemudahan dan kemanfaatan berpengaruh positif terhadap minat nasabah dalam menggunakan internet banking di PT. Bank BNI Syariah Cabang Bogor. Ditandai bahwa persepsi kemudahan dengan nilai Chi Kuadrat hitung yaitu 84,37 lebih besar dari nilai Chi-Kuadrat tabel yaitu 11,341. Sedangkan persepsi kemanfaatan di tandai dengan nilai Chi Kuadrat hitung yaitu 123,28 lebih besar dari nilai Chi-Kuadrat tabel yaitu 11,341.

\section{DAFTAR PUSTAKA}

Akhlaq, Mohammed Ather. 2011. Internet banking di Pakistan, Jurnal internet banking dan perdagangan, Vol.16 terdapat

pada(http://www.arraydev.com/commer ce/jibc/).[di akses pada 02 oktober 2011]

Arif Surachman. 2008. "Analisis Penerimaan Sistem Informasi Perpustakaan (SIPUS) Terpadu Versi $3 \quad$ Di Lingkungan Universitas Gadjah Mada (UGM)". Jurnal, Perpustakaan Digital UIN Sunan Kalijaga Yogyakarta.

Dwi Adi K. 2001. Kamus Praktis Bahasa Indonesia.

Gilang Rizky Amijaya. 2010. "Pengaruh persepsi teknologi informasi, kemudahan, resiko dan fitur layanan terhadap minat ulang nasabah bank dalam menggunakan internet banking (studi pada nasabah bank BCA). 
Skripsi, Fakultas Ekonomi Universitas Diponegoro.

Hadri Kusuma dan Dwi Susilowati. 2007."Determinan Pengadopsian Layanan Internet Banking: Perspektif Konsumen Perbankan Daerah Intimewa Yokyakarta".Jurnal JAAI, Vol. 125, No. 2.

Nadia Ella Comaneci. 2009. "Tinjauan hukum terhadap perlindungan hukum nasabah pengguna internet banking berdasarkan undang-undang informasi dan transaksi elektronik". Tesis, Pascasarjana Universitas Sumatera Utara.

Najib Khalid Al-Amir dalam Anisah Hany N. 2004. "Analisis Minat Calon Nasabah Terhadap Pengajuan Pembiayaan di BMT Ibadurrahman." Skripsi, Fakultas Studi Islam Universitas Djuanda; Bogor, Tidak diterbitkan.

Oktavianti dalam Arif Surachman. 2008. Analisis Penerimaan Sistem Informasi Perpustakaan (SIPUS) Terpadu Versi 3 Di Lingkungan Universitas Gadjah Mada (UGM).Jurnal, Perpustakaan DigitalUIN Sunan Kalijaga Yogyakarta

Rahadi, Dedi Rianto. "Peranan TI Dalam Peningkatan Pelayanan Di Sektor Publik". Naskah dipersentasikan pada Seminar Nasional Teknologi 2007 ; Yogyakarta.

Ronny Kountur. 2010. Metode Penelitian Untuk Penulisan Skripsi Dan Tesis.

Shinta EkaKartika. 2009. Analisis Proses Penerimaan Sistem Informasi Icons Dengan Menggunakan Technology Acceptance Model Pada Karyawan PT. Bank Negara Indonesia (Persero) Tbk. Di Kota Semarang. Tesis, Program Studi Magister Akuntansi Program Pasca Sarjana Universitas Diponegoro.

Suharini, Mieke. "Persepsi Nasabah terhadap Penerapan Sistem Layanan Produk dan Jasa E Banking". Jurnal Ilmu Administrasi dan Organisasi "Bisnis \& Birokrasi“Vol.15 (No.3), Sept-Des 2008, Institut Ilmu Sosial dan Ilmu Politik, Jakarta.
Supriyono, Maryanto. 2011. "Buku pintar perbankan." Penerbit Andi ; yokyakarta, hal 52.

Tidjan. 2010. "Pengertian Minat Belajar" tersedia pada http://belajarpsikologi.com/pengertianminat/ [16 januari 2012]

Titis Widyastuti. 2008. "Pengaruh persepsi kemudahan penggunaan, persepsi manfaat dan kepercayaan konsumen terhadap pengaplikasian layanan mobile banking studi kasus di kota Yogyakarta." Skripsi, Program Studi Akuntansi Fakultas Ekonomi Universitas Islam Indonesia, Yogyakarta.

Wijayanti, Ratih. 2009. " Analisis Technology Acceptance Model (TAM) Terhada Faktor-Faktor Yang Mempengaruhi Penerimaan Nasabah Terhadap Layanan Internet Banking (Studi Empiris Terhadap Nasabah Bank Di Depok)". Jurusan Akuntansi, Fakultas Ekonomi - Universitas Gunadarma. 